\title{
Puritan Hindus in Bolaang Mongondow: Faith, Trade and Politics
}

\author{
Almunawar Bin Rusli ${ }^{1 *}$, Nasruddin Yusuf ${ }^{2}$ \\ 1,2IAIN Manado, North Sulawesi, Indonesia \\ *<almunauwar.binrusli@iain-manado.ac.id>
}

\begin{abstract}
This article look at how to become a Balinese in Bolaang Mongondow, North Sulawesi. As a trans-migrant group from the eruption of Mountain Agung Karangasem 1963, they left the Island of Gods since March 11, 1964, anchored in Makassar later arrived in Bolaang Mongondow March 26, 1964 through Inobonto port and build of Pakraman Kembang Mertha Village November 1, 1965 with permission of Dumoga indigenous peoples. The Balinese expression of faith shaping of intersubjective relation. In contrast to Geertz's thesis about the absolute monism of Hinduism, the Balinese in Bolaang Mongondow instead used of religious pluralism perspective. They convert to Muslim and Christian without conflict. In 1970, the Bali farmers start to planting corn, soybean, cassava and rice based on family ties. They have a trade networks with Chinese ethnic descendants. In presidential election 2019, Joko WidodoMa'ruf Amin became the winner in Kembang Mertha (84.56\%) in comparison to PrabowoSandi (15.44\%). The loyalty of Balinese to PDIP can be survived from money politics and identity politics because of the cross-blood and ideology. Thus, Balinese migrants can be classified as one of the strongest civil society in contemporary Bolaang Mongondow.
\end{abstract}

Keywords: Balinese, Faith, Trade, Politics, Bolaang Mongondow

\section{Introduction}

The relationship between desire and togetherness cannot be separated from Indonesian history. The two mutually influence public interpretation. After the eruption of Mount Agung Karangasem on March 17, 1963 (the same as Eka
Dasa Rudra ceremony at Besakih Temple), the Balinese people suffered greatly, died and were frustrated. 1,549 people were killed, 1,700 houses were destroyed and 225,000 people lost their livelihoods. The thousand islands became the island of a thousand sorrows. This disaster later encouraged 
Balinese people to embrace the diaspora.

They left the Island of the Gods since March 11, 1964, anchored in Makassar then arrived at Bolaang Mongondow March 26, 1964 via the Inobonto port and built Pakraman Kembang Mertha Village on November 1, 1965 with the permission of the Dumoga indigenous people. Bolaang Mongondow is located in the northern peninsula of Sulawesi Island adjacent to Minahasa. This area has many plains, mountains and rivers. Bolaang Mongondow area is 8,359.04 square kilometers. For more than 50 years, they have held the status of trans-migrants and are seen as a society with an exotic mystical spirit.

We question why the influence of modernization and westernization on Bali island cannot change the religious commitment of the Balinese in Dumoga to environmental resilience? The portrait of obedience is even more prominent. Even though they are more devout, at the same time many Balinese in Dumoga have converted to other religions (Islam-Christian). Regrettably, a comprehensive explanation of this ongoing conversion phenomenon is still very difficult for us to find in other studies.

Second, economically, if we look at the level of work displayed in each Village Office, the farmer profession is in the highest rank and most favored by Balinese people in Bolaang
Mongondow apart from doctors, teachers or police. At this point, we also have not found an explanation of how Balinese farmers can create communal solidarity, organize commercial relations and spread farming doctrine to their families.

Third, why was the Indonesian Democratic Party of Struggle (PDIP) able to win the majority votes in Mertha Raya Kembang Village during the 2019 presidential election? Not only that, why couldn't the money politics and identity politics movements diminish the loyalty of the local Balinese people to PDIP? The void of perspective and analysis above is important to be further explored in order to know the "other face" of post-Suharto Balinese Hinduism, which was known to be authoritarian and repressive among civil society.

\section{Research and Field Work}

In order to research Balinese life and its relationship with these Hindu doctrines, we use various approaches including historical studies (articlearchives), ethnographic studies, including analysis of narrative and statistical data sourced from printed and electronic media. Alex Jhon Ulaen is very helpful in this regard. In addition, symbols and practices of Balinese religion and culture are a major concern in providing an objective interpretation. Overall, we took advantage of 14 days in December 2019 to start a 
participatory observation phase, structured interviews and then collected supporting documentation.

With an effort like this, at least we can understand the faith of the Balinese people in Kembang Mertha who are constantly presenting, evolving and changing, the history of agriculture, the trade process as well as the general description of their political choices regarding State power. As outsiders, we were quite successful in building good relations with the Balinese people there thanks to the full help of Monita F.K. Mamahit. They consist of religious leaders, farmer groups and political volunteer teams.

\section{Faith, Trade, and Politics}

Understand Faith Variation of Balinese People

In this section, we would like to say that Balinese people in the land of Dumoga still deeply maintain Hindu worship tradition. They worship supernatural powers commonly known as Brahman. Brahman is believed to be a god who has a relationship with ancestral spirits. Each house in Kembang Mertha Village has a small temple. This has become an ethical obligation for them. They acknowledge that this holy place is the best area for praying, making pilgrimages or praying. Its main purpose is to control kama (evil desire). Balinese people make Hinduism a religious and cultural system puritanically. Thus, their faith is deeply rooted in the dimensions of knowledge, mental and personality

Hindu religious leaders in the Kembang Mertha Village get a respectable position in the eyes of the Balinese people there. They are Mangku I Dewa Rai Marutawan, Mangku Dewa Swija, Mangku I Wayan Ngented, Jro Gede Wayan Mustiade and Mangku I Kadek Swita. They are used to leading large rituals such as Ngaben and Galungan. Ngaben means purification of the soul from the body and final liberation from rebirth. This doctrine emphasizes the return of the soul (atman) into transcendent union with God. This unity can be achieved through ethically correct behavior and the ritual of cremation or moksa. [1] Meanwhile, Galungan symbolizes the victory of good over evil and the enforcement of piety practices in the Balinese religious system.[2]

I Gede Pariasa and his family whom we met still hold on to this belief and continue to pass it on to their children even though they have been separated from their ancestral land on the Island of the Gods. Historically, the Balinese believed that the spirits of their ancestors would come down to earth and stay in the houses of their descendants five days before Galungan day. All houses and utensils are provided along with the offerings. In the front yard of the house, a high penjor was erected so that the gods could see from the top of the mountain. 
Penjor is decorated with a small bamboo altar hung with lamak made of coconut leaves. The length is not more than thirty feet and must be hung from the top of the coconut trunk. White clothes and gold keris (dagger) are the characteristics of Galungan.

The god worshiped by Balinese people in Galungan does not mean to refer to Indian Hinduism, but rather refers to the spirits of protective ancestors such as sanghyang, pitara and kawitan.[3] Galungan marks the beginning of the most important religious ceremonies. The Balinese people believe that the spirits of their ancestors will return home that day, and it is their duty to welcome them with prayers and offerings.[4]

In the eyes of I Gede Pariasa, Galungan is classified as a sacred event to improve quality and motivate oneself to always live in diligent work without forgetting personal safety or preservation of nature. Women in the Pakraman Kembang Mertha Village always wear traditional Balinese clothes, hold offerings on their heads and are accompanied by their husbands or children to the family temple for prayers. After observing the Galungan celebration process, we began to understand that Balinese people have four variations of social harmony.

First, it is family harmony on the basis of sapinda or gotra which is symbolized by the Kawitan Temple. Second, territorial harmony based on continuous cooperation between those who live together in an area symbolized by the Tri Kahyangan Desa temple. Third, professional harmony based on cooperation between those who have the same job which is symbolized by Pura Swagina. Fourth, universal harmony on the basis of cooperation between Balinese ethnicities without distinguishing the social strata symbolized by the Kahyangan Jagat Temple.

Even so, we will propose other findings that have the potential to revise Geertz's thesis which says that Balinese religion contains polytheism and mythological values. The people do not have a clear idea of God and are far from being rational.[5] Geertz's thesis is based on his observations on the practice of Balinese people who often perform religious rituals involving natural elements such as soil, statues, trees, forests, rivers and mountains. Ultimately, this view culminates in an animism judgment. Even though the thesis above is somewhat wrong. Balinese people's expressions of faith in Dumoga are actually transformativetraditional. They use strong religious feelings and intuition.

We find that there is an intersubjectivity relationship that is at the core of Balinese faith which is very agrarian. This relationship believes that between humans and non-humans can become subjects. According to them, nature in Dumoga is built on 
the relationship between subjects, not subject-object. Everything that exists in nature such as soil, statues, trees, forests, rivers, and mountains is a living being that has purity and metaphysical power. This relationship is always bound by sacred religious vows which show that every agreement formed between them is not only a bond between the two parties, but also involves the intervention of Ida Sang Hyang Widhi Wasa. If it is violated, then all members of the community will get disaster.

Maarif argues that this intersubjectivity relationship can be processed in three principles, namely responsibility, ethics, and reciprocity. Responsibility means that every subject in this relationship has a responsibility that must be done to ensure the welfare of the subjects in the relationship. Ethics means the awareness that what one subject does will have an impact on other subjects in the relationship. Reciprocity means a reciprocal relationship, that what I give is what I will get, or what I get is actually what I have given.[6]

Balinese people in Dumoga have succeeded in connecting between expressions of faith and environmental sustainability. This is where the rationality dimension begins to influence the lives of local communities. God, man and nature are always united in this relationship. Budi Luhur Private Senior High School (SMAS), which was established in 2008, is used as the main educational institution to teach this model of faith to their children in the Kembang Mertha Village. The school is led by I Dewa Gede Rai Sastrawan.

In the same study, Geertz's thesis which claims that even though Balinese Hindus have interacted with Islam and Christianity, they will never change religions, however we think it also needs to be renewed. This is because Balinese Hindus who have lived for generations in the Dumoga Valley have experienced a theological paradigm shift from monism to pluralism. They no longer see that only Hinduism can provide a way of salvation to heaven but religions outside Hinduism also have the same way of salvation as long as they can find inner and outer peace. Sociologically, Kembang Mertha Village, which is located in the East Dumoga area, is indeed very diverse. The population of Islam is 2626 inhabitants, Christian is 14002 inhabitans, and Hindu is 3317 inhabitants.[7] This paradigm can be proven through the phenomenon of religious conversion. They converted to Christian and Islam without any conflicts.

I Gusti Ketut Kautra is the first example. He has converted to Christian since he married his wife from Minahasa ethnic. Previously, he also had intense associations with interfaith communities since studying in Manado. He works as a civil 
servant elementary school teacher who often teaches religious lessons. For him, Christian provides more social, political and economic security. Religious conversion is a sociological phenomenon. True conversion occurs only when there is a reorientation of the soul. I Nyoman Kawi is the second example. He had embraced Islam at a young age due to the influence of the Tablighi Jemaah teachings which guaranteed the safety of the world and the hereafter through the application of Islamic law. Theoretically, social, political and economic forces are the main factors driving the process of religious conversion. Hefner argues that an individual can commit to a particular belief system because the results of social development which promote the comparison of faith with other forms of belief.[8]

Balinese Farmers and Trade Network in the New Order Era

Balinese farmers are hard workers in order to improve the welfare of their loved ones. In 1970, they started planting corn, soybeans, cassava and rice based on family ties. This kind of culture gives rise to communal solidarity. They continue to care for this tradition to the next generation. The land they live in is divided among all villages, especially those that have irrigation so that everyone knows the land. No one from another village can work on it. They rarely sell land unless passed on to their descendants. The land was agreed as a common property and the laws of the gods applied in it.

In the context of the New Order (1965-1998), Ricklefs pointed out that in the 1988 decade, the people saw the real advantages of the Suharto regime: electricity in rural areas, construction of schools and clinics, abundant rice and money, moderate inflation and the possibility of a better future for their children. The trans-migrant groups received construction projects and a growing industry.

However, I Gede Pariasa stated that in 2004 their land was sued by the local community because it was considered that the land was only a loan, not an absolute right. Local people ask for money to make their land legal. Balinese ethnic disagreed with the reason that the land was the result of the policies of the Old Order which ruled from 1945-1965. Demonstrations were carried out up to Manado. Sentiment and social jealousy are getting thicker. The Balinese and Dumoga ethnic relations heat up. In the end, Balinese ethnic also paid for their land there with government assistance. For us, this event at least encourages Balinese ethnic to always protect their nature, a symbol of struggle for the real. Some of the senior farmers there were I Nengah Paing (1930), Ni Ketut Raning (1939), Ni Luh Sukra (1940), I Nyoman Repin (1957), I Nengah Tunas (1962), I Ketut Stay (1964), I Nengah Rita (1965) and I Gede Surinu (1967). 
However, in 1990, they experienced water irrigation problems. Thus, the land becomes unproductive. They then take advantage of the river flow through the help of a pump machine where the water is sucked and then flowed to their rice fields. Apart from that, they are also talented breeders of pigs, cows, ducks and chickens.

Balinese farmers can be hard workers regardless of their historical background. Ricklefs argues that the Balinese economy in the early nineteenth century was still heavily dependent on the export of slaves. Around 2000 people were sold by Balinese aristocrats every year. However, within two decades, Bali turned into an exporter of agricultural products such as rice, coffee and Nile tilapia. Each King assigned them to cultivate farmland.[9] We think this explanation is strong enough to claim that it is very possible for Balinese peasants to inherit kinesthetic intelligence as a result of colonialism and feudalism. Kinesthetic intelligence is the ability of people to use their whole body or physics to express their ideas and feelings. Including the expertise to use hands to change or create something new. It is in this phase that communal solidarity can be formed.

To make money, Balinese farmers tried to build a trade network with Chinese ethnic descendants in Dumoga, namely Liong Robot and Nyam Kong. This trade network is divided into two forms, namely a warehouse for processing crops or commonly known as a mill and four-wheeled transportation to bring their produce to the trading center in Kotamobagu. Serasi Market is the heart of Balinese buying and selling activities. The market is a symbol of the multiethnic and multi-religious space there. Ethnic Javanese, Bugis, Gorontalo and Arabic who are affiliated with Islam are serious competitors for them. Even so, Balinese farmers claim to receive good service from Chinese ethnic. Meanwhile, Liong and Kong saw them as diligent, honest, disciplined and not proud farmers. Besides material, the point of view of brotherhood is considered more important. The influence of Chinese ethnic descendants in the business sector in Bolaang Mongondow has been quite strong since the beginning of the twentieth century. This farming tradition continues to be inherited by the Balinese to their families through the doctrine of inter-subjectivity relations as we have previously described. We assume that Balinese farmers in Dumoga are more likely to nurture Indonesian nationalism through cultural rather than structural paths. They can still live in prosperity without having to become State Civil Apparatus.

Balinese People's Politics Under the PDIP Flag

From the perspective of the nineteenth century, Geertz argued that in Balinese belief, the higher political 
goal was to build the state by building the life of the king. The more perfect the king, the better his rule. Thus, the people's welfare will be more real. Every ritual performance always produces a jero-jaba (inner-outer) relationship as an ideal and pragmatic symbolic reality. So, it can strengthen social order.[10]

Kembang Mertha Village which is inhabited by the majority of Balinese people is always crowded when the presidential election period is coming, especially in the 2019 period. This village was divided into Kembang Sari, Amertha Sari and Amertha Buana. Their land is believed to be the fortress of a flag bearing a bull's head symbol. While the flags bearing the Garuda head symbol are very few. I Gede Pariasa, I Wayan Prasetyo and I Wayan Wiranata who we met admit that Balinese loyalty to the Indonesian Democratic Party of Struggle (PDIP) can withstand attacks from money politics and identity politics because of the cross-blood factor and ideology that has been deeply rooted since the nineteenth and twentieth century.

The blood crossing here refers to the marriage between Raden Soekemi from the Javanese priyai caste and Ida Ayu Nyoman Rai from the Balinese brahman caste in 1897. Soekemi later became Soekarno's biological father who taught that school and politics are weapons to form a prosperous country. On this side we agree with
Geertz's thesis on kings. In the eyes of the Balinese, Soekarno was the king of the republic who had to be served clothes, food and a place to live. This was proven by the founding of the Tampaksiring Palace in 1957. Soekarno's cosmological legitimacy was because he inherited the sanctity of the Brahman god from his biological mother. The blood crossing factor then creates a strong emotional-spiritual bond.

In the ideological context, Ricklefs argued that the main basis of the Indonesian National Party (PNI) which Soekarno founded in 1927 were bureaucrats and office workers. In rural Java, PNI had a special appeal for abangan Muslims who did not agree with Masjumi's political policies. PNI's political ideology has inspired areas outside Java, such as Bali. PNI has a lot of support by Hindus people in Bali. This cannot be separated from the first factor. Today, the Balinese still feel that the PDIP is a political party that still holds firmly to the PNI ideology. Megawati is also believed to be a woman who is able to protect minority interests and ensure their survival through the leadership of Joko Widodo and KH Ma'ruf Amin. Below are the results of the official vote count for the 2019 presidential election in the Dumoga Valley.[11]

This loyalty to political choices further strengthens our thesis on the cross-blood factor and ideology. 
Tabel 1. The results of 2019 presidential election votes in Balinese village of Bolaang Mongondow

\begin{tabular}{lcc}
\hline Balinese Village & $\begin{array}{c}\text { Joko Widodo-KH Ma'ruf } \\
\text { Amin } \\
\text { (Presidential and Vice } \\
\text { Presidential candidate of } \\
\text { PDIP) }\end{array}$ & $\begin{array}{c}\text { Prabowo Subianto-Sandiaga S. Uno } \\
\text { (Presidential and Vice Presidential } \\
\text { candidate of Gerindra) }\end{array}$ \\
\hline Kembang Mertha & $84,56 \%$ & $15,44 \%$ \\
& $(493$ votes $)$ & $(90$ votes $)$ \\
\hline Kembang Sari & $88,52 \%$ & $11,48 \%$ \\
& $(455$ votes $)$ & $(59$ votes $)$ \\
\hline Amertha Sari & $79,15 \%$ & $20,85 \%$ \\
& $(391$ votes $)$ & $9,66 \%$ \\
& $90,34 \%$ & votes $)$ \\
\hline Amertha Buana & $(374$ votes $)$ & votes $)$ \\
\hline
\end{tabular}

Source: www.pemilu2019.kpu.go.id

Meanwhile, Balinese Muslims in the village mostly chose Gerindra Party because of the Islamic doctrine that was spread through mosques, scholars and social media (Facebook). However, Agung Ani, whom we met at Jagadhita Temple Manado, argued that these two models of loyalty could be shaken if the country's leaders failed to produce freedom, justice and brotherly bonds. He chose Joko Widodo and KH Ma'ruf Amin because they were believed to be humanists and religious people. We see that KH Ma'ruf Amin's influence was also very important in this victory due to the existence of the Nahdlatul Ulama (NU) Network.

Apart from having many members (57.33 million people), NU also has experience in Indonesian politics. Ricklefs and Fealy show that since 1952, NU left Masyumi because of differences in religious doctrine and discrimination in the distribution of power. Masyumi is too sectarian while NU is more cosmopolitan. NU formed its own political party under the control of Wachid Hasjim and then collaborated with PNI for a long period of time.[12]

\section{Closing}

Finally, we can conclude that the phenomenon of religious, commercial and political connections of Balinese Hindus in Dumoga makes them one of the strongest civil society in contemporary Bolaang Mongondow. This civil power is manifested in a great opportunity for them to obtain citizens' rights, preserve social identity and develop ideas about political participation in the public sphere without being disturbed by ethnicity, religion, race and other indigenous groups there.[] 


\section{References}

[1] Volker Gottowik (Editor), Dynamic of Religion in Southeast Asia : Magic and Modernity, Amsterdam : Amsterdam University Press, 2014.

[2] Helen Creese, Bali in the Early Nineteenth, Leiden : Brill, 2016.

[3] Miguel Covarrubias, Island of Bali, Denpasar : Udayana University Press, 2014.

[4] Fred B. Eiseman Jr., Bali Sekala and Niskala: Essays on Religion, Ritual and Art, Amazon: Tuttle Publishing, 1989.

[5] Clifford Geertz, Internal Conversion in Contemporary Bali, in Interpretation of Culture, New York: Basic Book, 1973.

[6] Samsul Maarif, Indigenous Religion Paradigm: Re-interpreting Religious Practices of Indigenous People, Journal of Studies in Philosophy, 2019.

[7] Badan Pusat Statistik Kabupaten Bolaang Mongondow, 2017.

[8] Ariel C. Lopez, Conversion and Colonialism: Islam and Christianity in North Sulawesi, c. 1700-1900, Thesis Ph.D Leiden University 2018.

[9] M.C. Ricklefs, A History of Modern Indonesia Since c.1200-2004, Palgrave McMillan,2001.

[10] Clifford Geertz, Negara: The Theatre State in Nineteenth-Century Bali. Princeton, NJ: Princeton University Press, 1980.

[11] Laporan Komisi Pemilihan Umum (KPU) RI. www.pemilu2019.kpu.go.id.

[12] Greg Fealy, Ulama and Politics in Indonesia : a History of Nahdlatul Ulama 1952-1967, Yogyakarta : LKiS,2003. 